\title{
Intraabdominal abscess after cholecystectomy: Do not forget the stones
}

\author{
Varathan N*, Hess G, Nocera F, Lazaridis I and Posabella A \\ University Center for Gastrointestinal and Liver diseases, 4002 Basel, Switzerland
}

\begin{abstract}
Gallbladder perforation is one of the frequent complications in laparoscopic cholecystectomy, which can cause a loss of gallstones in the abdominal cavity. Usually these are removed. But in cases where they are not completely removed it can cause intraabdominal abscess even years after. Here we present a patient who was admitted with a sepsis due to an intraabdominal abscess.
\end{abstract}

\section{Introduction}

Acute cholecystitis is one of the most frequent encountered acute abdominal diseases worldwide. The prevalence of gallstones is reported in a range between $10 \%$ and $15 \%$ among adults [1]. Cholesterol gallstones account for $80-90 \%$ in western societies. Approximately $80 \%$ of gallstones remain asymptomatic [2,3], 1-2\% of individuals with gallstones become symptomatic each year $[2,4]$. Of those with symptomatic gallstones, $10 \%$ will develop an acute cholecystitis [5]. In people younger than 50 years, women are three times more likely than men to develop an acute cholecystitis [6]. Laparoscopic cholecystectomy is the standard treatment for acute cholecystitis [7].

The timing of surgical intervention in acute cholecystitis is still a subject of ongoing studies. Initial studies concluded that early laparoscopic cholecystectomy for acute cholecystitis was associated with a higher conversion rate, more complications and longer surgery times [8]. However, with advances in laparoscopic techniques, early laparoscopic cholecystectomy became the standard practice for treatment of acute cholecystitis [7].

One of the common complications of laparoscopic cholecystectomy is a gallbladder perforation [9]. The incidence varies from 1.3 to $40 \%[10,11]$. This can cause gallstone spillage, which in most cases remain clinically asymptomatic, however in 0.04 to $19 \%$ of the cases adverse events were reported [11].

The intra-abdominal abscesses formation is the most frequent complication [12]. The presence of pigment stones is correlated to development of complications [12]. We present the case of sepsis due to intraabdominal abscess years after laparoscopic cholecystectomy.

\section{Case presentation}

In July 2018, a 78-year-old male patient presented at the emergency room in an outside hospital with acute right upper quadrant pain and nausea for two days. In the prior weeks he suffered from intermitting fever, loss of appetite and loss of weight. His medical history was remarkable for status post laparoscopic cholecystectomy in 2000 where gallstones were lost and left in the peritoneal cavity. In cause of a sepsis with the need of surveillance in an intensive care unit the patient was moved to our hospital. Infection signs in the blood (white blood cells and CRP) were clearly elevated. The computer tomography (CT) of the abdomen confirmed an abdominal abscess in the right lower quadrant close to the colon ascendens. A CT-guided drainage of the abscess collection was performed, and we began an antibiotic treatment with Piperacillin/Tazobactam $4.5 \mathrm{~g}$ three times a day. Due to the cardiac situation and the anticoagulation with Marcoumar (due to an atrial fibrillation) with an INR $>2$ an operative treatment could not be performed. The result of the puncture fluid showed enterobacter aerogenes, the antibiotic therapy was adjusted according to the resistance profile to Imipenem $4 \times 500 \mathrm{mg}$. The following CT after two weeks showed a new abscess collection in the iliac and lesser pelvic area, a second drainage was necessary. After another 2 weeks a third drainage had to be placed in another collection in the left paracolic area. Over time the symptoms dissolved, and the infection signs remained normal. The antibiotic treatment was changed to Ciproxin $2 \times 500 \mathrm{mg}$ and Co-Amoxicillin $3 \times 625 \mathrm{mg}$ p.o. and all three drainages were removed. After 40 days the patient was discharged to a rehabilitation facility.

\section{Discussion}

In laparoscopic cholecystectomy the chances for incomplete retrieval of spilled stones in case of lost gallstones are higher than in open cholecystectomy. Spilled gallstones can lead to numerous longterm complications, with abdominal wall abscess and intra-abdominal abscess being the most frequent [9]. Peritoneal gallstones create an inflammatory process leading to partial or complete reabsorption of the stone, abscess formation, granulomatous reaction and even erosion to other abdominal organs $[9,13]$. Infected stones, which are more likely to happen in case of pigmented stones, intensify this process [9]. Studies show that $80-83 \%$ of surgeons may underestimate the number of potential complications, which indicates, that this subject requires

*Correspondence to: Nadshathra Varathan, Kleinriehenstrasse 304058 - Basel, Switzerland, E-mail: nadshathra.varathan@clarunis.ch

Received: June 12, 2019; Accepted: June 25, 2019; Published: June 28, 2019 
increased clinical attention [12]. Perforation of gallbladder and spillage is poorly reported in operation note [12]. Therefore, late complication of perforated gallbladder should be considered in any patient who had a laparoscopic cholecystectomy in the past [12]. In this case we did not perform an operative treatment because of the high perioperative risk concerning the cardiac situation. That means the lost gallstones were not removed. But the abscess collections disappeared in the CT-control, the patient remained asymptomatic and did not show any elevated infection signs over time. Still whenever possible an operative treatment should be sought. The lost gallstones can be removed laparoscopically. The advantage of the laparoscopic surgery is that the abdominal cavity can be explored compared to a conservative or open surgery.

\section{Conclusion}

Lost gallstones can cause long-term complication even several years post-surgery. As our case showed with CT- or ultrasound-guided drainage and antibiotic treatment a sufficient therapy can be achieved in patients with high perioperative risk.

\section{References}

1. Portincasa P, Moschetta A, Palasciano G (2006) Cholesterol gallstone disease. Lancet 368: 230-239. [Crossref]

2. Friedman GD (1993) Natural history of asymptomatic and symptomatic gallstones. $\mathrm{Am}$ J Surg 165: 399-404. [Crossref]

3. Gibney EJ (1990) Asymptomatic gallstones. Br J Surg 77: 368-372. [Crossref]

4. Friedman GD, Raviola CA, Fireman B (1989) Prognosis of gallstones with mild or no symptoms: 25 years of
5. follow-up in a health maintenance organization. J Clin Epidemiol 42: 127-136. [Crossref]

6. Ko CW, Lee SP (2003) Gastrointestinal disorders of the critically ill. Biliary sludge and cholecystitis. Best Pract Res Clin Gastroenterol 17: 383-396. [Crossref]

7. Indar AA, Beckingham IJ (2002) Acute cholecystitis. BMJ 325: 639-643. [Crossref]

8. Mou D, Tesfasilassie T, Hirji S (2009) Advances in the management of acute cholcystitis. Ann Gastroenterol Surg 3: 247-253. [Crossref]

9. Kum CK, Eypasch E, Lefering (1996) Laparoscopic cholecystectomy for acute cholecystitis: is it really

10. safe?. World J Surg 20: 48-49. [Crossref]

11. Kaplan U, Shpoliansky G, Abu Hatoum O, Kimmel B, Kopelman D (2018) The lost stone - laparoscopic exploration of abscess cavity and retrieval of lost gallstone post cholecystectomy: a case series and review of the literature. Int J Surg Case Rep 53: 43-45. [Crossref]

12. Memon MA, Deeik RK, Maffi TR, Fitzgibbons RJ Jr (1999) The outcome of unretrieved gallstones in the peritoneal cavity during laparoscopic cholecystectomy: a prospective analysis. Surg Endosc 13: 848-857. [Crossref]

13. Jabbari NA, Hassanpour M, Jangjoo A (2016) Consequences of lost gallstones during laparoscopic cholecystectomy: a review article. Surg Laparosc Endosc Percutan Tech 26: 183-192. [Crossref]

14. Ross Clemmesen TB, Achiam MP, Pedersen CR (2018) [Gallstones lost during laparoscopic cholecystectomy

15. may cause severe complications. Ugeskr Laeger 180(29). pii: V10170787.] Danish. [Crossref]

16. Woodfield JC, Rodgers M, Windsor JA (2004) Peritoneal gallstones following laparoscopic cholecystectomy:

17. incidence, complication and management. Surg Endosc 18: 1200-1207. [Crossref]

Copyright: $₫ 2019$ Varathan N. This is an open-access article distributed under the terms of the Creative Commons Attribution License, which permits unrestricted use, distribution, and reproduction in any medium, provided the original author and source are credited. 